Canadian Oncology

Nursing Journal

Revue canadienne

de soins infirmiers

en oncologie

Volume 31, Issue 3 • Summer 2021

elSSN: 2368-8076 


\title{
Knowledge, attitude and health beliefs on cervical cancer screening in Ajumako-Eyan-Essiam District, Ghana
}

\author{
by Charlotte Naa Sampson, Samuel Donkor Nkpeebo, Thywill Amenuveve Degley
}

\begin{abstract}
The study assessed women in Ajumako-Eyan-Essiam District (AEED) on knowledge, attitude, and health beliefs on cervical cancer screening. In Ghana, cervical cancer ranks as the second leading cause of female cancers. In clinical practice and studies done on women with cervical cancer, early diagnosis, treatment, and prevention of cervical cancer is widely influenced by women's knowledge, and attitude towards screening, yet there is no study on knowledge, attitude, and health beliefs among women in AEED. A quantitative cross-sectional design was used, with a descriptive statistical analysis of data from 240 women. The results showed that $61.3 \%$ of women do not know which organs cervical cancer affects or when to follow up after a normal smear, which might suggest some deficit in their level of knowledge. Thirty-six percent believed that the Pap test is done once and $57.1 \%$ were of the view that it is expensive, which limits patronage. The majority of respondents refused to go for screening for fear of the unknown (48.8\%) while others believed that they might not be at risk (65.8\%). A significant number (46.7\%) were of the view that cervical cancer cannot be cured. In conclusion, the inadequate knowledge and false health beliefs of women influenced their attitude toward cervical cancer screening.
\end{abstract}

Key words: cervical cancer, knowledge, screening, attitude, health beliefs, treatment, Pap smear, human papillomavirus (HPV)

\section{AUTHOR NOTES \\ Charlotte Naa Sampson, Tutor, Nursing and Midwifery Training College, Teshie, TS861, Accra, Ghana, cdasampson18@gmail.com \\ Samuel Donkor Nkpeebo, Assistant Lecturer, Family Health University College, Teshie, Accra, Ghana, samdonkor.nkpeebo@gmail.com \\ Thywill Amenuveve Degley, Clinical Coordinator, Stanford World Clinic, Cape Coast, Ghana, tamenuveve@gmail.com}

DOI: $10.5737 / 23688076313285290$

\section{INTRODUCTION}

ancer of the cervix uteri is the third most common cancer among women worldwide, with an estimated 569,847 new cases and 311,365 deaths in 2018 (Bruni et al., 2019). About $83 \%$ of the cases occur in developing countries, where women present late and only palliative treatment can be given. About 14,943 new cervical cancer cases are diagnosed annually in Nigeria (estimates for 2018). In Ghana, about 3,151 new cervical cancer cases are diagnosed annually (estimates for 2018), making it the second leading cause of female cancer after breast cancer (Bruni et al., 2019). The variation between these countries lies in the population size where the population of Nigeria records 209 million and $21.3 \%$ are female within the ages of 18 to 64 (Adenola \& Saifu, 2017). In Ghana, $6,530,900$ women are aged $18-64$ years out of a total population of 24,658,823 (26.5\%) (Ghana demographics, 2015). Despite the staggering statistics, cervical cancer prevention is not commonly promoted in Ghana.

An estimated $95 \%$ of women in developing countries have never been screened for cervical cancer (Tung et al., 2010) and only $2.1 \%$ of Ghanaian women have ever had a Pap smear (Adanu et al., 2010). Cervical cancer is largely preventable by effective screening programs and considerable reduction in cervical cancer incidence and deaths has been achieved with systematic cytological smear screening programs. However, in Ghana, screening services are available only at a few locations, mostly in the urban centres, and most women would have to travel to get it done. In a study by Mukama et al. (2017) in eastern Uganda, most women also lack knowledge of the availability or purpose of screening and for some, even though they were screened, they do not present themselves for follow-up and further healthcare once an abnormality is detected in their smear results. For the screening methods to be fully utilized, women need to be aware of the availability of the methods, have knowledge of the disease, and abolish some false health beliefs. This was also confirmed by Ebu et al. (2015), who reported that the health beliefs of women, as well as their knowledge and attitudes, may be the reason for low coverage of cervical cancer screening in Ghana. Thus, cervical cancer still remains a public health concern.

Furthermore, it has been reported that understanding health behaviours in the cultural context is paramount if the health status of a high-risk group is to be improved (Mattocks et al., 2014). Hence, exploring women's knowledge base, as well as their attitudes and health beliefs associated with cervical cancer screening, will likely help to increase their screening uptake and reduce morbidity and mortality rates associated 
with the disease. This may also help to generate the interest of other researchers to conduct research into this area and add to the existing body of knowledge.

The objective of the study was to examine the effect of knowledge, attitude, and health beliefs on cervical cancer screening in the Ajumako-Eyan-Essiam District in southern Ghana.

\section{METHODOLOGY}

The research was conducted in the Ajumako-EnyanEssiam District in the republic of Ghana. Ajumako-EnyanEssiam (Ghana Districts, 2006) is one of the 17 districts in the Central Region of Ghana. It is a rural area with an estimated land coverage of 541.3 square kilometers. This constitutes 5\% of the Central Regional land area. On the west, Assin District forms the boundary, on the South is Mfantsiman District, on the north-west is Asikuma-Odoben-Brakwa (AOB) District, and to the east is Gomoa District (Ghana Districts, 2006). It has a projected population of 138,046 of which 73,628 are females (GSS \& Macro, 2015). It is made up of 169 communities.

The study adopts the cross-sectional study design. This design allows the researcher to gather data on a defined group of people or population at a single point in time or time interval. The data collection period spanned a period of four months between July 2019 to November 2019.

The population of the study included females between the ages of 18 to 64 years who lived in the geographical area of Ajumako-Enyan-Essiam District. The study excluded pregnant women and females within the age group who had a history of cervical cancer. This exclusion is because pregnancy comes with its own set of discomforts and the strenuous exercise of cervical cancer testing could be a great discomfort for this category of women. Also, these categories of women are highly prone to infections.

The study employed a non-probability sampling procedure of stratification and convenience in determining the sample size through the following sample procedures. First, the 169 towns in the district were stratified into four main groups, using the boundaries in the district: Northern, Southern, Eastern and Western parts (Ghana Districts, 2006). After the district was stratified, two towns were selected from each stratum with a simple random sampling technique using the ballot method. A total of eight towns were selected. Convenience sampling procedures were adopted to select participants in each town. The total sample size $(\mathrm{N}=204)$ that was selected for the study was based on the statistical formula by Glenn (1992). The sample size was increased to 240 to compensate for non-response. Hence, out of the 240 respondents, each town had approximately 30 participants.

A self-administered questionnaire was developed on knowledge, attitudes, and health beliefs. The instrument was designed for the study's purposes. The questions aimed to gather information regarding respondent's knowledge, attitudes, and health beliefs on screening for cervical carcinoma.
To ensure an effective and efficient data collection procedures, nurses who understood the local dialect were engaged as research personnel in each community and worked together with the researcher to help respondents effectively undertake the data collection exercise. Prior to selecting and engaging these nurses as research personnel, a series of meetings were held to ensure the nurses understood the objectives of the study and the role expected of them.

The women were approached in the community and the study and questionnaire were explained to them. The women who agreed to participate were given time to answer that same day. The questionnaires were enclosed in a self-addressed envelope including a cover letter and a pen as an incentive to enhance maximum participation in the research. Each respondent signed a consent form, after a detailed explanation was given, to ensure the right of self-determination and autonomy. Respondents sealed the envelopes after completion of the questionnaires to ensure utmost confidentiality. To retrieve all responses, the research personnel went around to ensure that respondents filled the questionnaires after the principal investigator had finished explaining and distributing the questionnaires. The researcher and the research personnel collected the questionnaire after being filled by the respondents.

The data collected were analyzed with SPSS and descriptive statistics used to identify frequencies of responses to each question.

\section{RESULTS}

\section{Level of knowledge about Pap smear}

The sample of 240 consisted of females who resided in the Ajumako-Enyan-Essiam District within the ages of 18 to 64 years. A little more than two (2) out of every five (41.7\%) respondents were within the ages of 21 to 30 , and $39.6 \%$ were 31 to 40 years old. However, 8.2\% were between 51 to 60 years. In terms of marital status, more than half $(51.7 \%)$ of the women were married while $2.9 \%$ were divorced or separated. Slightly more than half $(53.3 \%)$ of the women had secondary level education while $24.2 \%$ had tertiary level education.

With regards to their knowledge level, a majority of the respondents (74\%) reported they had heard of Pap smear tests. However, only $47.5 \%$ of the women surveyed understood that a normal cervical cancer test means low risk of developing the disease, while $25 \%$ said they were not at risk of developing the disease. It must be noted that $15.8 \%$ did not know what a normal test meant. $58.3 \%$ of the respondents reported that follow-up after a normal test result must be done in six months while $22.9 \%$ reported two months. However, $15.4 \%$ did not know when it was appropriate for women to go for follow-ups (see Table 1).

Thirty-five (35\%) percent of the respondents reported that HPV is the main cause of cervical cancer while more than half (59.6\%) attributed it to multiple sexual partners. Approximately half of the respondents $(50.8 \%)$ reported women who take hormonal contraceptives are at increased risk while $10.8 \%$ did not know whether they were at increased risk or not. The majority $(75.9 \%)$ were of the view that a Pap smear is performed by gynecologists. In this study, about a third of the respondents 


\begin{tabular}{|c|c|c|}
\hline \multicolumn{3}{|c|}{$\begin{array}{l}\text { Table 1: Level of Knowledge of Women on Cervical Cancer and } \\
\text { Pap Smears }\end{array}$} \\
\hline Knowledge on cervical cancer & Frequency & Percentage \\
\hline \multicolumn{3}{|l|}{ Cervical cancer is } \\
\hline Cancer of the cervix & 58 & 24.2 \\
\hline Cancer of the ovaries & 14 & 5.8 \\
\hline Cancer of the vagina & 147 & 61.3 \\
\hline Cancer of the tubes & 9 & 3.8 \\
\hline Don't know & 12 & 5.0 \\
\hline \multicolumn{3}{|l|}{ Main cause of cervical cancer } \\
\hline Early sexual intercourse & 26 & 10.8 \\
\hline Multiple sexual partners & 143 & 59.6 \\
\hline Multiparty & 33 & 13.8 \\
\hline Low socio-economic status & 3 & 1.3 \\
\hline Human papilloma virus infection & 35 & 14.6 \\
\hline \multicolumn{3}{|l|}{ Ever heard of Pap smear test } \\
\hline Yes & 178 & 74.0 \\
\hline No & 62 & 36.0 \\
\hline \multicolumn{3}{|l|}{ Normal smear results means } \\
\hline Low risk of developing disease & 114 & 47.5 \\
\hline No risk of developing disease & 60 & 25.0 \\
\hline $\begin{array}{l}\text { I don't need to have any further } \\
\text { smear tests }\end{array}$ & 28 & 11.7 \\
\hline I don't know & 38 & 15.8 \\
\hline \multicolumn{3}{|l|}{ Follow-up for normal smear results } \\
\hline 6 months & 140 & 58.3 \\
\hline 2 months & 55 & 22.9 \\
\hline One year & 8 & 3.3 \\
\hline Three years & 0 & 0.0 \\
\hline I don't know & 37 & 15.4 \\
\hline \multicolumn{3}{|l|}{$\begin{array}{l}\text { Women who take contraceptives are } \\
\text { at risk }\end{array}$} \\
\hline Yes & 122 & 50.8 \\
\hline No & 92 & 38.3 \\
\hline Don't know & 26 & 10.8 \\
\hline \multicolumn{3}{|l|}{ Who performs Pap smear } \\
\hline Nurse & 28 & 11.7 \\
\hline General practitioner & 30 & 12.5 \\
\hline Gynecologist & 182 & 75.9 \\
\hline \multicolumn{3}{|l|}{$\begin{array}{l}\text { At what stage are women likely to have } \\
\text { cervical cancer }\end{array}$} \\
\hline $18-25$ & 78 & 32.5 \\
\hline $26-35$ & 59 & 24.6 \\
\hline $36-60$ & 49 & 20.4 \\
\hline Not more than 70 & 12 & 5.0 \\
\hline Don't Know & 42 & 17.5 \\
\hline Total & 240 & 100 \\
\hline
\end{tabular}

$(32.5 \%)$ reported that women are likely to have cervical cancer at age 18-25 years while $24.6 \%$ reported between $26-35$ years. However, $17.5 \%$ of them did not know the age at which women were likely to have cervical cancer (see Table 1).

\section{Experience regarding cervical cancer screening}

As shown in Table 2a, one-quarter $(25.4 \%)$ of the respondents had had a Pap smear while $73.3 \%$ had never had one. Only $6.3 \%$ of the respondents reported going for Pap smear themselves and $5 \%$ went because it was suggested by doctors. Most respondents (65\%) reported that they preferred to have it in a hospital while $20 \%$ reported that they preferred a screening site. Others reported that they had no preference. A majority of the respondents were of the impression that cervical cancer is bad. However, $11.7 \%$ of the respondents could not tell whether it was good or bad (see Table 2a).

\section{Respondents' attitude towards cervical cancer screening}

Two-thirds (67.5\%) of the respondents reported that cervical cancer screening cannot be helpful. Yet, almost all $(98.8 \%)$ of the respondents revealed that they were interested in cervical cancer screening. All $(100 \%)$ were of the view that

\begin{tabular}{|c|c|c|}
\hline Experience of cervical cancer screening & $\begin{array}{c}\text { Frequency } \\
n(240)\end{array}$ & $\begin{array}{c}\text { Percent } \\
(\%)\end{array}$ \\
\hline \multicolumn{3}{|l|}{ Have you had a Pap smear } \\
\hline Yes & 61 & 25.4 \\
\hline No & 176 & 73.3 \\
\hline Don't know & 3 & 1.3 \\
\hline \multicolumn{3}{|l|}{ How often do you go for Pap smear } \\
\hline Once in a year & 27 & 11.3 \\
\hline Once every three years & 12 & 5.0 \\
\hline Once every five years & 0 & 0.0 \\
\hline Once every 10 years & 6 & 2.5 \\
\hline Not applicable & 195 & 81.3 \\
\hline \multicolumn{3}{|l|}{ Barriers to screening (Pap smear) } \\
\hline You asked for it & 15 & 6.3 \\
\hline Doctor suggested & 12 & 5.0 \\
\hline Taken routinely & 12 & 5.0 \\
\hline Other reason & 6 & 2.5 \\
\hline Not applicable & 195 & 81.3 \\
\hline \multicolumn{3}{|l|}{ Impression about cervical cancer screening } \\
\hline Good & 23 & 9.6 \\
\hline Bad & 189 & 78.8 \\
\hline None & 28 & 11.7 \\
\hline
\end{tabular}


they will encourage other women to participate in screening. Only $9.6 \%$ reported that their religion has something against cervical cancer screening, but $96.7 \%$ reported that their culture forbids cervical cancer screening. A majority of the respondents $(72.5 \%)$ reported that the thought of cancer scared them, though only $27.9 \%$ thought they were susceptible to cervical cancer. More than four-fifths $(82.9 \%)$ of the respondents felt cervical cancer test is important to them (see Table 2b).

\section{Health beliefs about cervical cancer screening}

Approximately a third (34.2\%) of the respondents were of the belief that they could have precancerous lesions while $24.6 \%$ did not know. A majority $(95 \%)$ perceived that cervical cancer is a public health concern. Half $(49.6 \%)$ held the view that there is the chance of cure for cervical cancer. A majority of the respondents $(96.7 \%)$ reported that cancer of cervix is not a curse and $90.4 \%$ held the view that they would be satisfied after having a Pap smear. Three-quarters of the respondents (78.8\%) reported that regular Pap smear gave them a sense of control and most $(79.6 \%)$ believed Pap smear should be done on a regular basis (see Table 3).

\section{DISCUSSION}

In this study, a majority of the respondents reported that they had heard of cervical cancer screening. This finding is of primary importance, as having knowledge about a preventive

\begin{tabular}{|l|c|c|c|c|}
\hline \multicolumn{3}{|l|}{ Table 2b: Respondents' attitude towards cervical cancer screening } \\
\hline Attitudes & Yes & No & Don't Know & Total \\
\hline $\begin{array}{l}\text { Are you interested } \\
\text { in participating in } \\
\text { screening? }\end{array}$ & $237(98.8)$ & $3(1.3)$ & $0(0.0)$ & $240(100)$ \\
\hline $\begin{array}{l}\text { Will you encourage } \\
\text { other women to } \\
\text { participate }\end{array}$ & $240(100.0)$ & $0(0.0)$ & $0(0.0)$ & $240(100)$ \\
\hline $\begin{array}{l}\text { Does the thought } \\
\text { of cancer scare } \\
\text { you? }\end{array}$ & $174(72.5)$ & $66(27.5)$ & $0(0.0)$ & $240(100)$ \\
\hline $\begin{array}{l}\text { Do you think you } \\
\text { are susceptible to } \\
\text { cervical cancer? }\end{array}$ & $67(27.9)$ & $158(65.8)$ & $15(6.3)$ & $240(100)$ \\
\hline $\begin{array}{l}\text { Do you feel } \\
\text { cervical cancer } \\
\text { test is important } \\
\text { to you? }\end{array}$ & $199(82.9)$ & $20(8.3)$ & $21(8.8)$ & $240(100)$ \\
\hline $\begin{array}{l}\text { Going for Pap } \\
\text { smear check is too } \\
\text { expensive. }\end{array}$ & $137(57.1)$ & $100(41.7)$ & $3(1.3)$ & $240(100)$ \\
\hline $\begin{array}{l}\text { I am afraid } \\
\text { something wrong } \\
\text { will be detected. }\end{array}$ & $117(48.8)$ & $123(51.3)$ & $0(0.0)$ & $240(100)$ \\
\hline
\end{tabular}

Table 3: Health beliefs about cervical cancer screening

\begin{tabular}{|c|c|c|}
\hline Health beliefs & Frequency & Percent \\
\hline \multicolumn{3}{|l|}{$\begin{array}{l}\text { Belief that you could have precancerous } \\
\text { lesion }\end{array}$} \\
\hline Yes & 82 & 34.2 \\
\hline No & 99 & 41.3 \\
\hline Don't know & 59 & 24.6 \\
\hline Total & 240 & 100 \\
\hline \multicolumn{3}{|l|}{$\begin{array}{l}\text { Do you think cervical cancer is public } \\
\text { health concern }\end{array}$} \\
\hline Yes & 228 & 95.0 \\
\hline No & 12 & 5.0 \\
\hline Total & 240 & 100 \\
\hline \multicolumn{3}{|l|}{$\begin{array}{l}\text { What do you believe there is the chance of } \\
\text { cure for cervical cancer }\end{array}$} \\
\hline Good Chance & 119 & 49.6 \\
\hline Not so good chance & 78 & 32.5 \\
\hline Don't know & 43 & 17.9 \\
\hline Total & 240 & 100 \\
\hline \multicolumn{3}{|l|}{ Do you believe cancer can be cured } \\
\hline Yes & 119 & 49.6 \\
\hline No & 112 & 46.7 \\
\hline Don't know & 9 & 3.8 \\
\hline Total & 240 & 100 \\
\hline \multicolumn{3}{|l|}{$\begin{array}{l}\text { Do you believe cancer of cervix is a curse } \\
\text { from the gods }\end{array}$} \\
\hline Yes & 1 & 0.4 \\
\hline No & 232 & 96.7 \\
\hline Don't know & 7 & 2.9 \\
\hline Total & 240 & 100 \\
\hline \multicolumn{3}{|l|}{$\begin{array}{l}\text { Will be satisfied after having a cervical } \\
\text { cancer test }\end{array}$} \\
\hline Yes & 217 & 90.4 \\
\hline No & 3 & 1.3 \\
\hline Don't know & 20 & 8.3 \\
\hline Total & 240 & 100 \\
\hline \multicolumn{3}{|l|}{$\begin{array}{l}\text { Does regular test give you a sense of } \\
\text { control }\end{array}$} \\
\hline Yes & 189 & 78.8 \\
\hline No & 21 & 8.8 \\
\hline Don't know & 30 & 12.5 \\
\hline Total & 240 & 100 \\
\hline \multicolumn{3}{|l|}{$\begin{array}{l}\text { Do you believe cervical Pap smear should } \\
\text { be done regularly }\end{array}$} \\
\hline Yes & 191 & 79.6 \\
\hline No & 41 & 17.1 \\
\hline Don't know & 8 & 3.3 \\
\hline Total & 240 & 100 \\
\hline
\end{tabular}


measure for a health condition influences the attitude and practice of such individuals positively and makes it easier for individuals to accept and promote policies that have to do with such conditions. In other studies, assessments of knowledge or awareness among the general population revealed that individuals are often ignorant of cervical cancer, its identification as a sexually transmitted disease and its screening. Findings from Nigeria indicated that the vast majority of women had never even heard of HPV (Bang et al., 2011). Preliminary analysis among university-aged females in Nigeria revealed that women who had received a Pap test were more knowledgeable about cervical health than those who had not (Gimba et al., 2014). In a study conducted in Zimbabwe et al. (2011), 81\% of the 514 participants had no previous knowledge of cervical screening tests.

The World Health Organization (2019) confirmed that many women and men have not heard of cervical cancer and do not recognize early signs and symptoms when they occur. Additionally, women at risk may not be aware of the need to be tested even when they do not have any symptoms (WHO, 2019) because of the lack of knowledge about the disease. This would suggest that most women who participated in screening services are those with knowledge of the disease. Moreover, the female genital tract is often considered private, and women may be shy about discussing symptoms related to it (WHO, 2019). Destigmatizing discussion of the female genital tract in the form of awareness creation, may be an important strategy for encouraging women to be screened and seeking care if they have symptoms suggestive of cervical cancer. The respondents in this study did not have in-depth knowledge about cervical cancer and screening services, which may have resulted in the low patronage of screening services.

Most women in the study did not know what cancer of the cervix was and did not have accurate knowledge about its screening. This was consistent with other international studies which showed that women do not have sufficient knowledge about cervical cancer risk factors and Pap smear (Saha et al., 2010). WHO (2019) reported that, in many places, creation of cervical cancer awareness has been ignored by decision makers, healthcare providers, and the population at large resulting in inadequate knowledge about the disease and its preventive measures.

Several studies, including a study of college women by Baer et al. (2000), confirmed that the majority of college-level students are ignorant about cervical infection, the modes of transmission, and its prevalence in society. Similar to the respondents in this study, knowledge about HPV was low, as less than half identified HPV as a main cause of cervical cancer. These respondents must be educated on the various aspects of the disease condition and on new methods of screening and testing. Many studies have shown that the knowledge level of women increased through health education given to them about the prevention of cervical cancer and resulted in them having a Pap smear test or were eager to have it in the post-education period (Yücel et al., 2009).
In this study, most respondents reported that women are likely to have cervical cancer at age 18-25 years and, as such, should go for testing. This was consistent with a study organized by United States Preventive Task Force (2018) that indicated screening women within this age group substantially reduces cervical cancer incidence and mortality. These findings were consistent with a study conducted in Accra, the capital of Ghana, in 2009 among college students. The majority of the students who responded were interested in screening because they were sexually active and could be exposed to the virus through sexual activity. For this reason, it is necessary to raise awareness about having a regular Pap smear test in order to prevent cervical cancer and cure it through early diagnosis. Additionally, a majority of the respondents do not know when follow-up should occur after a normal smear. It was recommended by the America Cancer Society that the number of years for follow-up after a normal smear was three years.

In terms of behaviour of respondents, less than $10 \%$ in this study had had a Pap smear. This could have been influenced by their age and educational levels. Studies have reported a positive association between one's educational level and attitude towards health initiatives with increased knowledge being positively associated with higher levels of screening. With the low level of knowledge about Pap smear testing, it is not surprising that going for the testing is low among respondents in this study. The Health Belief Model suggests that women who are more likely to undergo cervical smear testing are those who perceived themselves as vulnerable to cervical cancer, believe in the efficacy of the test, perceive the procedure as not painful, and receive a professional recommendation (Rosenstock et al., 1994). A majority of the respondents reported that they thought of cancer as scary and were afraid of the test results. Some studies have found that heightened knowledge of cervical cancer may lead to increased anxiety, which could make it less likely to adhere to screening regimes (Blomberg et al., 2009). In the same way, some respondents $(57.1 \%)$ were of the view that screening is expensive, which limits patronage. This was confirmed in a study done in Ghana by Ampofo (2020) that screening uptake were significantly affected by high cost.

The assertion that women in this study did not think they had precancerous lesions may influence their attitude towards the screening. Respondents who feel they could not have precancerous lesions will not actively involve themselves in most aspects of the disease. One possible explanation for these results could be that many women have the impression that if they do not experience signs and symptoms of the disease then they may not find screening very important. Yet, in this study, a majority of respondents were of the perception that cervical cancer is a public health concern. This perception is of primary importance, as this will positively influence the attitude of such individuals towards any action to curb this condition. Analysis of data from a study conducted in Netherlands (Tacken et al., 2007) showed that woman's beliefs about cervical screening is one of the best predictors of screening uptake, even when demographic and organizational aspects are taken into account. 
Based on the study findings the following actions are offered:

1. Women within the relevant age group, and especially those living in rural areas, must be educated on the various aspects of cervical cancer screening and Pap smears. The public health nurses in the various communities should be trained on cervical cancer to help create awareness in schools and during community durbars (i.e., meetings).

2. Policies to enhance access to cervical screening test must be implemented to ensure wider coverage among women.

3. Cervical cancer screening and Pap smear test must be incorporated into the curriculum of tertiary institutions to increase the awareness and knowledge of women.

\section{REFERENCES}

Adanu, R. M. K., Seffah, J. D., Duda, R., Darko, R., Hill, A., \& Anarfi, J. (2010). Clinic visits and cervical cancer screening in Accra. Ghana medical journal, 44(2).

Adenola, F., \& Saibu, O. M. (2017). Does population change matter for long run economic growth in Nigeria. International Journal of Development and Sustainability, 12(6), 1955-1965.

Ampofo, A. G., Adumatta, A. D., Owusu, E., \& Awuviry-Newton, K. (2020). A cross-sectional study of barriers to cervical cancer screening uptake in Ghana: An application of the health belief model. PloS one, 15(4), e0231459

Baer, H., Allen, S., \& Braun, L. (2000). Knowledge of human papillomavirus infection among young adult men and women: implications for health education and research. Journal of community health, 25(1), 67-78.

Bang, K. S., Sung, S., Koo, B., Kim, M., Kim, Y., Kim, J., \& Ryu, S. (2011). Female university students' HPV-related knowledge and influencing factors on HPV vaccination. Journal of Korean Oncology Nursing, 11(3), 186-192.

Blomberg, K., Forss, A., Ternestedt, B. M., \& Tishelman, C. (2009). From 'silent'to 'heard': Professional mediation, manipulation and women's experiences of their body after an abnormal Pap smear. Social science a medicine, 68(3), 479-486.

Bruni L, Albero G, Serrano B, Mena M, Gómez D, Muñoz J, Bosch F X, de Sanjosé, S. (2019). Human Papillomavirus and related diseases in Ghana.

Ebu, N. I., Mupepi, S. C., Siakwa, M. P., \& Sampselle, C. M. (2015). Knowledge, practice, and barriers toward cervical cancer screening in Elmina, Southern Ghana. International Journal of Women's Health, 7, 31-39. https://doi.org/10.2147/IJWH.S71797

Ghana Districts. (2006). Ajumako-Enyan-Essiam district Assembly. Min of Local Government Q R Rural Dev. and Maks Publications \& Media Services. http://aeeda.ghanadistricts.gov.gh

Gimba, S. M., Emmanuel, A., Afoi, B. B., Mangai, M. J., \& Bukuta, G. (2014). Awareness and practice of cervical cancer screening among University of Jos female undergraduates. Continental J. Nursing Science 6(1), 1-11.

Glenn, D. I. (1992). Determining sample size. A series of the Program Evaluation and Organizational Development. University of Florida. Publication date: November.

GSS, G., \& Macro, I. C. F. (2015). Ghana demographic and health survey 2014. Ghana Statistical Service, Ghana Health Service, and ICF International.
4. Policy makers should consider integrating cervical cancer screening activities with primary health services and accord the disease the same priority as other priority diseases such as malaria, tuberculosis, HIV, and hypertension.

5. Further study on the subject should be undertaken that widens the scope of this study to other districts.

\section{CONCLUSION}

This study has shown that respondents had poor knowledge about cervical cancer screening, as well as false health beliefs about the disease and its screening. These factors influenced their attitude towards screening uptake.

Mattocks, K. M., Kauth, M. R., Sandfort, T., Matza, A. R., Sullivan, J. C., \& Shipherd, J. C. (2014). Understanding healthcare needs of sexual and gender minority veterans: How targeted research and policy can improve health. LGBT health, 1(1), 50-57.

Mupepi, S. C., Sampselle, C. M., \& Johnson, T. R. (2011). Knowledge, attitudes, and demographic factors influencing cervical cancer screening behavior of Zimbabwean women. Journal of Women's Health, 20(6), 943-952.

Mukama, T., Ndejjo, R., Musabyimana, A., Halage, A. A., \& Musoke, D. (2017). Women's knowledge and attitudes towards cervical cancer prevention: A cross sectional study in Eastern Uganda. BMC women's health, 17(1), 1-8.

Rosenstock, I. M., Strecher, V. J., \& Becker, M. H. (1994). The health belief model and HIV risk behavior change. In Preventing AIDS (pp. 5-24). Springer.

Reis, N., Bebiş, H., Köse, S., Sis, A., Engin, R., \& Yavan, T. (2012). Knowledge, behavior and beliefs related to cervical cancer and screening among Turkish women.

Saha, A., Chaudhury, A. N., Bhowmik, P., \& Chatterjee, R. (2010). Awareness of cervical cancer among female students of premier colleges in Kolkata, India. Asian Pac J Cancer Prev, 11(4), 1085-90.

Tacken, M. A. J. B., Braspenning J. C. C., Hermans, R. P. M. G., et al. (2007). Uptake of cervical cancer screening in The Netherlands is mainly influenced by women's beliefs about the screening and by the inviting organization. Eur J Public Healh, 17(2), 178-85.

Tung, W. C., Lu, M., \& Cook, D. (2010). Papanicolaou screening in Taiwan: Perceived barriers and self-efficacy. Health care for women international, 31(5), 421-434.

US Preventive Services Task Force. (2003). Screening for cervical cancer: Recommendations and rationale. AJN The American Journal of Nursing, 103(11), 101-109.

Yücel, U., Ceber, E., \& Özentürk, G. (2009). Efficacy of a training course given by midwives concerning cervical cancer risk factors and prevention. Asian Pac J Cancer Prev, 10(3), 437-442.

World Health Organization. (2019). WHO framework for strengthening and scaling-up of services for the management of invasive cervical cancer. World Health Organization.

World Health Organization. (2013). Transforming and scaling up health professionals' education and training: World Health Organization guidelines 2013. World Health Organization. 